\title{
Colorectal Cancer in Young Adult Population in Kashmir Valley: Tertiary Care Centre Experience
}

\author{
Peerzada Umar Farooq Baba', Ajaz Ahmad Malik ${ }^{2}$, Yaqoob Hassan ${ }^{3}$, Khursheed Alam Wani ${ }^{4}$, \\ Abdul Rashid Lone \\ 'Department of Plastic surgery SKIMS, ${ }^{2}$ Department of General and Minimal Invasive Surgery, SKIMS \\ ${ }^{3,4}$ General and Minimal Invasive Surgery, SKIMS Medical College, ${ }^{5}$ Department of Medical Oncology, SKIMS
}

\section{A B S T R A C T}

Background: Colorectal cancer (CRC) has been defined and discussed as a disease of middle or late life. However, no age-group is exempt, and adenocarcinoma of the colon has been reported in young age. Malignant disease is frequently found in young adults in our Kashmir valley. Objective (s): This aim was to study the clinicopathological features, diagnosis, management and outcome of colorectal cancer in young adults under the age of 40 .

Material and Methods: This combined Retrospective (January 2002 to May, 2004)Prospective (June 2004 to September 2006) Observational Study was conducted in the Department of General and Minimal Access Surgery, SKIMS. A total of 62 young colorectal carcinoma patients were studied. The case records of all the patients of colorectal cancer less than 40years of age admitted in the Department of General and Minimal Access Surgery were reviewed retrospectively. In the prospective study, all the patients less than 40 years of age with colorectal carcinoma admitted in our department were registered. Following the confirmation of diagnosis, the patients were subjected to exploratory laparotomy. The nature of the surgical procedure depended upon the intra-operative findings. All the patients were subjected to postoperative chemotherapy and in selected cases to postoperative chemo-radiation. The patients were followed up in General and Minimal Access Surgery and Medical Oncology out patient departments conjointly. The patients were thoroughly examined and investigated on follow up to rule out any recurrence or metastasis.

Results: Most of our patients (83.9\%) were admitted through outpatient department (OPD) and only 10 patients (16.1\%) were admitted through the Emergency Department. In our study, the male: female ratio was1.58: 1.The mean age in our study was 30.2 years. Bleeding per rectum was the most common $(74.2 \%)$ presenting symptom followed by altered bowel habits $(72.6 \%)$. Carcinoembryonic antigen (CEA) levels show significant decline after surgery/adjuvant therapy. Colonoscopy detected synchronous growths in $5.3 \%$ of patients. Rectum was the most common site of lesion (32.2\%) while combined rectum and sigmoid colon (including recto sigmoid) accounted for $62.7 \%$ of lesions. Resection with intention of cure was performed in $68.3 \%$ of patients, palliative procedure in $26.7 \%$ and biopsy in $5 \%$ of patients. Postoperative complications were recorded and managed accordingly. Typical adenocarcinoma was seen in $80.6 \%$ of patients. None of our patients had Dukes stage A presentation. $13.6 \%$ of patients had local recurrence and $25.4 \%$ had metastasis on follow up.

Conclusion: Colorectal cancers in young adults are quite common in Kashmir valley. Outcome of $\mathrm{CRC}$ in young patients is significantly related to the procedure - whether done with curative intention or for palliation. Henceforth, surgical treatment should be radical and optimized with adjuvant therapy where possible to achieve the best prognosis. The diagnosis of colorectal cancer should be done at the early and curable stage for better outcome.

Keywords: Colorectal cancer, Young Adults, Treatment

JMS: 2019;22(1):58-66 DOI:https://doi.org/10.33883/jms.v22i2.412

\section{INTRODUCTION}

Colorectal cancer (CRC) is the most common malignant cancer in the gastrointestinal tract. It represents $13 \%$ of all the malignant tumors, and is the second most common cause of death related to cancer affecting men as well as women in the same manner worldwide ${ }^{1-3}$. Colorectal cancer is the third

\begin{tabular}{|l|l|}
\multicolumn{2}{c}{ Access this article online } \\
\hline
\end{tabular}

most common type of cancer in oncologic pathology ${ }^{4}$. In the

Correspondence:

Dr. AjazAhmad Malik, MS

Professor \& Division Head,

Department of General and Minimal Invasive Surgery, SKIMS

Email:ajazamalik@rediffmail.com

How to cite this article: Baba PUF, Malik AA, Hassan Y, Wani KA, Lone AR. Colorectal Cancer in Young Adult Population in Kashmir Valley: Tertiary Care Centre Experience. jms [Internet]. 2019May31 [cited 2019Jun.8];22(2). Available from: http://www.jmsskims.org/index.php/jms/article/view/412

Received: 02-03-2019 Accepted: 11-05-2019 


\section{Baba PUF; et al; Colorectal Cancer in Young Adult Population in Kashmir}

U.S. colorectal cancer ranks third, only behind prostate cancer and lung cancer in males $(8 \%$ of all new cancer cases), and behind breast cancer and lung cancer in females ( $8 \%$ of all new cancer cases). Similarly, only lung cancer and prostate cancer are expected to claim more U.S. male lives than colorectal cancer in 2016, and only lung cancer and breast cancer are expected to take more U.S. female lives $(8 \% \text { of total cancer deaths for both genders })^{5}$. Colorectal malignancies are not as common in India as in most western countries. In India, it is the fourth most common cause of cancer in males and third most common cause of cancer in females ${ }^{6}$. The age standardized rate (ASR) for CRC in India is low at 7.2 per 100,000 population in males and 5.1 per 100,000 populations in women ${ }^{7}$.

Carcinoma of the colon and rectum is predominantly a disease of the elderly population. The pathology is diagnosed more frequently in younger patients, due to changed life style and the progressive aging of the population. However, no age group is exempt, and it had been described to occur in a stillborn by S. Ahlfeld in 1880 . The youngest documented patient of colonic malignancy was a 9 month old girl ${ }^{8,9,10}$. Adenocarcinoma is an unusual disease in patients under 40 years of age, and generally presents as advanced disease. It has been estimated that between 2 and $3 \%$ of colorectal cancers occur in patients younger than the age of 40 years ${ }^{11}$. Men have proportionately higher incidence of rectal cancer than women $^{12,13,14}$.

Younger patients usually have pre-malignant colonic disease, such as inflammatory bowel disease (IBD) or hereditary polyposis coli. However, denovo colorectal malignancy in younger individuals below 40 years of age is being recognized more frequently ${ }^{15}$.IBD's are found to be a predisposing factor in $5 \%$ of patients ${ }^{16}$.Young patients who have had ulcerative colitis (UC) for more than 5years are particularly predisposed to carcinoma of the colon. Colorectal cancer is a well-documented complication of Crohn's colitis and tends to occur at an earlier age than ordinary colon cancer ${ }^{17}$.

Among the genetic and hereditary factors, colonic polyposis syndromes, familial adenomatous polyposis (FAP) and its variants (Turcot, Gardner, and attenuated FAP) and MYH-associated polyposis are the most common. Hereditary nonpolyposis colon cancer (HNPCC) or Lynch syndrome comprises the non-colonic polyposis category. About $4-6 \%$ of patients of familial adenomatosis coli will have carcinoma before the age of 25 years and another $6 \%$ will be free of cancer until age of 65 years or more. Cancers have been reported at even earlier ages, from 13 to 15 years of age, but such cases seem to be very rare ${ }^{18}$. The shift to the western life style with the nutritional transition to increased dietary fat and decreased fiber intake may affect onset of colorectal cancer ${ }^{16}$.

The most common symptom of carcinoma of colon in young adults is passage of blood per rectum followed by abdominal pain ${ }^{19,20}$. The next most common symptom is change in bowel habits, mainly constipation ${ }^{20}$. Anemia and weight loss with abdominal pain and altered bowel habits have been encountered in more than half of the patients ${ }^{21}$. Other symptoms include abdominal mass and distention ${ }^{22}$. Intestinal obstruction (17\%) and perforation (9\%) may be the presentation. Greater tendency of intestinal obstruction and perforation of left sided tumors is well known. Significantly higher incidence of intestinal obstruction is seen in women than men while no sex difference is seen in perforation, while some reported higher incidence of perforation in women too ${ }^{23}$.

Studies have documented that the duration of symptoms is important in determining the outcome of the patients. A delay in presentation of young patients with colorectal cancer has been suggested to be an important factor in $\operatorname{prognosis}^{24,25,26}$. Patients identified within 90 days of onset of symptoms have survival rate of $37 \%$ while those who had symptoms for more than 90 days, have a survival rate reduced to $25 \%{ }^{27}$.

AIMS AND OBJECTIVES: The aim was to study the clinicopathological features, diagnosis, management and outcome of colorectal cancer in young adults under the age of 40 .

\section{MATERIALAND METHODS}

Study Design: Combined Retrospective-Prospective Observational Study

Study Area: The study was conducted in the Department of General and Minimal Access Surgery, Sher-i-Kashmir Institute of Medical Sciences, Soura, Srinagar.

Study Population: Patients of colorectal cancer less than 40 years of age admitted in Department of General and 
Baba PUF; et al; Colorectal Cancer in Young Adult Population in Kashmir

minimal Access surgery.

Study Sample: Our study consisted of 62 young colorectal carcinoma patients; retrospective review of 26 and a prospective study of 36 patients.

Methodology: The case records of all the patients of colorectal cancer less than 40years of age were reviewed retrospectively. These patients were then followed up in General Surgical and Medical Oncology OPD's conjointly. In the prospective group, all the patients less than 40 years of age with colorectal carcinoma admitted in the Department of General and Minimal Access Surgery were registered. After complete history and thorough physical examination, all the patients were subjected to baseline investigations (complete haemogram, kidney and liver function tests, blood sugar, serum electrolytes), carcinoembryonic antigen (CEA) levels, electrocardiogram, plain X-ray chest and abdomen (in patients presenting with obstruction), ultrasonography of abdomen/pelvis, upper gastrointestinal (UGI) endoscopy (in elective patients), contrast enhanced computerized tomography (CECT) of abdomen (in selected patients). All the elective patients were subjected to primary gastroenterology evaluation to exclude any other underlying primary disease. Though the genetic profile does affect CRC incidence and outcomes of treatment in young colorectal cancers, our patients were not subjected to genetic analysis because of its non-availability at the time of study.

Following the confirmation of diagnosis, the patients were subjected to exploratory laparotomy. Those patients with T3(Tumor grade 3)lesions were referred to the Department of Radiation Oncology for preoperative chemo radiation for down staging of the lesion before exploratory laparotomy. The surgical procedure performed depended upon the perioperative findings. Resection anastomosis with covering colostomy was done in selected patients followed by closure of the colostomy. In case of unresectable lesions simple palliative measures like colostomy or bypass was done.

The final staging was done according to the operative findings and histopathological examination of the resected specimen as per modified Duke's classification. All the patients were subjected to postoperative chemotherapy and, in selected cases, to postoperative chemo radiation.
During the follow up, the patients were thoroughly examined and investigations (CEA levels, USG abdomen, colonoscopy) done to rule out any recurrence or metastasis.

\section{RESULTS}

A retrospective review of 26 patients $(41.9 \%)$ and a prospective study of 36 patients $(58.1 \%)$ of young colorectal carcinoma patients $(n=62)$ was performed. Most of our patients (51 patients) were admitted through Outpatient Department (OPD) and only 10 patients (16.1\%) were admitted through Emergency Department.

In our study, there were $61.3 \%$ ( 38 ) male and38.7 \%( 24) female patients with male: female ratio of 1.58: 1 .The mean age in our study was 30.2 years and the youngest patient was 17 years old male. The age distribution is shown in table 1 . Five of our patients had chronic gastritis, four with duodenal ulcer and one with Chron's disease after gastroenterology evaluation. Two of our patients had family history of colorectal cancer and one had history of gastric carcinoma in first degree relatives.

Bleeding per rectum was the most common (74.2\%) presenting symptom followed by altered bowel habits (72.6\%). Weight loss was present in $67.7 \%$ of patients $(>5 \%$ of body weight within the last 6 to 12 months or evidence of change in clothing size) and was more common among females $(79.2 \%)$ than males $(60.5 \%)$. (Table 2$)$

In our study mean duration of symptoms was 7.5 months. Minimum duration of symptoms (3days) was in a male patient who presented with features of obstruction. Maximum duration of symptoms was 18 months. (Table 3)

Table 1: Age Distribution

\begin{tabular}{|l|l|l|l|}
\hline Age group (yrs) & Male & Female & Total \\
\hline$<$ or $=20$ & 3 & 0 & 3 \\
\hline $21-25$ & 10 & 3 & 13 \\
\hline $26-30$ & 7 & 10 & 17 \\
\hline $31-35$ & 11 & 5 & 16 \\
\hline $36-40$ & 7 & 6 & 13 \\
\hline Total & 38 & 24 & 62 \\
\hline P value & 0.146 & \\
\hline
\end{tabular}


Baba PUF; et al; Colorectal Cancer in Young Adult Population in Kashmir

Table 2: Symptoms of patients

\begin{tabular}{|l|l|l|l|}
\hline Symptoms & Male & Female & Total \\
\hline Bleeding per rectum & 28 & 18 & 46 \\
\hline $\begin{array}{l}\text { Altered Bowel Habits } \\
\text { - Constipation } \\
\text { - Diarrhea }\end{array}$ & 20 & 10 & 30 \\
- Both Alternating & 4 & 5 & 4 \\
\hline Weight Loss & 23 & 19 & 42 \\
\hline Pain Abdomen & 16 & 13 & 29 \\
\hline Anorexia & 14 & 11 & 25 \\
\hline $\begin{array}{l}\text { General body aches } \\
\text { and pains/weakness }\end{array}$ & 11 & 7 & 18 \\
\hline Tenesmus & 7 & 4 & 11 \\
\hline Vomiting & 5 & 4 & 9 \\
\hline Abdominal Distension & 5 & 4 & 9 \\
\hline Abdominal Mass & 3 & 1 & 4 \\
\hline Total & 38 & 24 & 62 \\
\hline
\end{tabular}

\section{Table 3 : Duration of Symptoms}

\begin{tabular}{|l|l|l|l|}
\hline $\begin{array}{l}\text { Duration of } \\
\text { Symptoms } \\
\text { (in months) }\end{array}$ & Male & Female & Total \\
\hline$<$ or=3 & 10 & 5 & 15 \\
\hline $4-6$ & 11 & 8 & 19 \\
\hline $7-9$ & 14 & 3 & 7 \\
\hline $10-12$ & 6 & 2 & 8 \\
\hline$>12$ & 7 & 6 & 13 \\
\hline Total & 38 & 24 & 62 \\
\hline P-Value & 0.868 \\
\hline
\end{tabular}

CEA levels were available in 21 retrospective and 33 prospective patients. In retrospective group, 57.1\% of patients show CEA level greater than $5 \mathrm{ng} / \mathrm{ml}$. In contrast, $78.8 \%$ of patients in prospective group show CEA level greater than $5 \mathrm{ng} / \mathrm{ml}$. Overall, CEA level was normal $(<3$ $\mathrm{mg} / \mathrm{ml}$ ) in $13 \%$ of patients, $3-5 \mathrm{ng} / \mathrm{ml}$ in $16.7 \%$ of patients, 5 $10 \mathrm{ng} / \mathrm{ml}$ in $33.3 \%$ of patients and more than $10 \mathrm{ng} / \mathrm{ml}$ in $37 \%$ of patients at presentation.CEA levels show a considerable decline after surgery and/or adjuvant therapy which was statistically significant $(\mathrm{p}<0.05)$.

Colonscopic/sigmoidoscopic examination was carried out in 38 patients. Synchronous growths were seen in two patients during colonoscopic examination. Most of the lesions $(n=18)$ were stenotic and cope could not be passed beyond the growth, 11 lesions were polypoid and 9 lesions were ulcerative growths. No proctoscopy / sigmoidoscopy /colonoscopy was done in 10 patients who presented as acute obstruction. 14 patients had proctoscopically diagnosed rectal growth.

Most common site was rectum (32.2\%) while combined rectum and sigmoid colon (including rectosigmoid) accounted for $62.7 \%$ of lesions. Among colonic lesions, left colonic lesions predominate. (Table 4) Right hemicolectomy was most common procedure performed in 13 patients $(21.3 \%)$. Growth was unresectable in 19 patients (Table 5).One patient refused the surgery and left against medical advice.

Two-thirds of the growths $(66.7 \%)$ were stenotic, $18.3 \%$ were polypoid and $15 \%$ ulceroinfilterative. In three-fourths of patients (45 patients) growth was fixed. Local extension was present in (44)73.3\% of patients. Lymph nodes were involved in (43)71.7\% of patients. Visceral metastasis in the form of liver metastasis, peritoneal metastasis, parietal wall metastasis, intestines was present in (13)21.7\% of patients.

\section{Table 4: Site of Lesion}

\begin{tabular}{|l|l|l|}
\hline Site Of Lesion & $\begin{array}{l}\text { No. of } \\
\text { patients }\end{array}$ & Percentage \\
\hline Rectum & 20 & 32.3 \\
\hline Sigmoid Colon & 15 & 24.2 \\
\hline Hepatic Flexure & 6 & 9.7 \\
\hline Splenic Flexure & 5 & 8.0 \\
\hline Recto sigmoid & 4 & 6.4 \\
\hline Caecum Colon & 4 & 6.4 \\
\hline $\begin{array}{l}\text { Hepatic Flexure and } \\
\text { Ascending }\end{array}$ & 2 & 3.2 \\
\hline Ascending Colon & 1 & 1.6 \\
\hline Descending Colon & 1 & 1.6 \\
\hline $\begin{array}{l}\text { Caecum and Ascending } \\
\text { Colon }\end{array}$ & 1 & 1.6 \\
\hline $\begin{array}{l}\text { Caecum ,Ascending Colon } \\
\text { and Descending Colon }\end{array}$ & 2 & 3.2 \\
\hline Rectum and Splenic Flexure & 1 & 1.6 \\
\hline Total & 62 & 100 \\
\hline
\end{tabular}

Table 5: Operative Procedures

\begin{tabular}{|l|l|l|}
\hline Operative Procedure & Number & Percentage \\
\hline Right Hemicolectomy & 13 & 21.3 \\
\hline Segmental Resection & 9 & 14.7 \\
\hline Abdominoperineal Resection & 9 & 14.7 \\
\hline Left Hemicolectomy & 5 & 8.1 \\
\hline Anterior Resection & 2 & 3.2 \\
\hline Low Anterior Resection & 2 & 3.2 \\
\hline Total Colectomy With Ileo -Rectal & 2 & 3.2 \\
Anastomosis & & \\
\hline Unresectable & & \\
Sigmoid Colostomy & 8 & 13.1 \\
Transverse Colostomy & 7 & 11.5 \\
Biopsy Only & 3 & 4.9 \\
By-pass(Ileotransverse) & 1 & 1.6 \\
\hline Total & 61 & 100 \\
\hline
\end{tabular}


Baba PUF; et al; Colorectal Cancer in Young Adult Population in Kashmir

Fifty three patients had uneventful postoperative hospital stay. Four patients $(6.5 \%)$ had wound infection. One patient (1.6\%) had wound dehiscence in which secondary suturing was done. One patient $(1.6 \%)$ had anastomotic leak in whom on 4th postoperative day exploratory laparotomy with peritoneal toilet and defunctioning ileostomy was performed. Ileostomy was later closed after 6 months. One patient $(1.6 \%)$ had retraction of colostomy in which refashioning of colostomy was done. One patient (1.6\%) had colostomy prolapse which was managed conservatively by saline packs and ice compresses.

The staging of malignancy was done after histopathogical reports. (Table 6 and 7 )

Table 6: Histopathology

\begin{tabular}{|l|l|l|l|}
\hline Histopathology & Male & Female & Total \\
\hline $\begin{array}{l}\text { Adenocarcinoma } \\
\text { - Well Differentiated } \\
\text { - Moderately }\end{array}$ & 15 & 11 & 26 \\
$\begin{array}{l}\text { Differentiated } \\
\text { - Poorly Differentiated }\end{array}$ & 8 & 5 & 13 \\
\hline $\begin{array}{l}\text { Mucinous } \\
\text { Adenocarcinoma }\end{array}$ & 4 & 4 & 11 \\
\hline $\begin{array}{l}\text { Signet ring cell } \\
\text { carcinoma }\end{array}$ & 3 & 1 & 8 \\
\hline Total cal & 38 & 24 & 4 \\
\hline
\end{tabular}

Table 7: Modified Duke's Staging

\begin{tabular}{|l|l|l|l|}
\hline & Male & Female & Total \\
\hline Stage A & 0 & 0 & 0 \\
\hline Stage B & 6 & 4 & 10 \\
\hline Stage C1 & 7 & 6 & 13 \\
\hline Stage C2 & 15 & 9 & 24 \\
\hline Stage D & 8 & 5 & 13 \\
\hline Total & 36 & 24 & 60 \\
\hline
\end{tabular}

Of the total of 61 patients on follow-up, 8 patients were found to have local recurrence. 15 patients had metastasis. Liver alone was the commonest site of metastasis found in 7 patients followed by ovary 4 patients, lung 2 patients, brain 1 patient, colostomy site 1 patient. Two patients had combined lung and liver metastasis.

\section{DISCUSSION}

From the time of the earliest medical writings to those of the present day, cancer has been defined and discussed as a disease of middle or late life. Likewise, carcinoma of the large intestine is usually thought of as a disease primarily affecting patients in the middle and elderly age group ${ }^{28}$.
However, no age-group is exempt, and adenocarcinoma of the colon has been reported in a 9 month old infant ${ }^{8}$.

This combined prospective-retrospective study was done to testify this observation. Although exact incidence rate cannot be provided by a hospital-based study, the information would be useful in showing patterns of malignancies in our region.

Patients of the age 40 years or less were selected in our study. Majority of the patients $(48.4 \%)$ presented in $3^{\text {rd }}$ decade of life. Only 3 patients $(4.8 \%)$ were less than 20 years of age and correlates well with reports of Cusack et al (1996) who reported only $4.8 \%$ of patients below 20 years of age ${ }^{29}$. Youngest patient in our study was a 17 year old male. Mean age in our series was 30.2 years. Mean age in our series is slightly lower than Walton et al (1976) series ${ }^{10}$. The reason for mean age being lower in our series is because majority of our patients presented in third decade of life. We have observed an increased incidence of colorectal cancers in young adults in our Kashmir. The study done by Iqbal QM et al. ${ }^{30}$ reports that colorectal cancers are quite common in Kashmir valley, that too in younger age group (15-34 year) both among males as well as females. Their study reports $10.5 \%$ of colorectal cancer cases among all new cancer patients in the age group of 15-34 year.

There were 38 males $(61.3 \%)$ and 24 females (38.7\%) in our series with male-female ratio of $1.58: 1$. These findings correlate well with male preponderance shown by some series with male-female ratio ranging between $1.5: 1$ to $1.7: 1^{31,15,32,33}$.

All of the patients present with more than two symptoms. Bleeding per rectum was the most common(74.2\%) presenting symptom followed by altered bowel habits(72.6\%). Weight loss was present in $67.1 \%$ and was more common in females. Most of our findings correlate well with the findings of Johnson andJudd (1959), Adloff et al (1986), and Lee et al (1994) $)^{31,19,34} .16 .1 \%$ of our patients present with features of obstruction and correlates well with those of Bullow (1980), Umpleby et al (1984), Domergue et al (1988) and Singh et al (2002) $)^{2,23,25,35}$.

There was a wide range of duration of symptoms with minimum duration of 3 days and maximum duration of 18 months. Mean duration of symptoms was 7.5 months. $45.2 \%$ of our patients had duration of symptoms for more than 6 months and it correlates well with that of Pitluk et al 


\section{Baba PUF; et al; Colorectal Cancer in Young Adult Population in Kashmir}

$(\mathbf{1 9 8 3})^{26} .16 .1 \%$ of our patients had short duration of symptoms (in days) and all of them were in obstruction and in those patients short duration of symptoms cannot be correlated with their stage. It did not reflect the actual onset, but a late complication of the disease as pointed out by Recelde et al (1974) ${ }^{20}$.

Colonoscopic / sigmoidoscopic examination was performed in 38 patients. Single lesion was seen in most (94.7\%) patients. Synchronous growths were detected in $5.3 \%$ of patients on colonoscopic examination. $61.3 \%$ of lesions in our study were diagnosed by sigmoidoscopy/ colonoscopy. Martin et al (1981) reported 40\% of lesions within the reach of sigmoidscope ${ }^{36}$.

CEA levels were available in 21 retrospective and 33 prospective patients. In retrospective group, $57.1 \%$ of patients show CEA level greater than $5 \mathrm{ng} / \mathrm{ml}$ which correlates with Cusack et al (1996) series with $51.7 \%$ of patients with CEA level greater than $5 \mathrm{ng} / \mathrm{ml}^{29}$. In contrast, $78.8 \%$ of patients in prospective group show CEA level greater than $5 \mathrm{ng} / \mathrm{ml}$. CEA levels show a considerable decline after surgery and/or adjuvant therapy which was statistically significant $(\mathrm{p}<0.05)$.Alici et al $(\mathbf{2 0 0 3})$ reported that the presence of high serum CEA levels are predictors of poor survival in young patients with colorectal carcinoma(37).Lin et al (2005) stated that CEA levels were significant predictor of the overall survival in young patients $^{38}$.

In our study most common site was rectum (32.3\%) followed by sigmoid colon $(24.2 \%)$ and correlates well with Smith et al (1989) reported 32\% lesions in rectum and 32\% in sigmoid colon ${ }^{39}$. Together rectum and sigmoid colon (including rectosigmoid junction) accounted for $62.7 \%$ of our cases.

In our study, right hemicolectomy was the most common $(21.3 \%)$ procedure performed followed by segmental resection (14.7\%) and abdomino-perineal resection (APR) (14.7\%). Curative resection was done in $68.3 \%$ of patients and procedure was palliative in $26.7 \%$ of patients. In rest ( $5 \%$ cases), only biopsy was taken at laparotomy. These findings correlate well with Ohman (1982) who reported $66.7 \%$ patients treated with intention of cure and $33.3 \%$ for palliation $^{40}$.

Majority of our patients had uneventful postoperative period. Four patients $(6.5 \%)$ had wound infection. One patient had wound dehiscence and secondary suturing was done in him. Anastomotic leak, colostomy prolapse and colostomy retraction was noted in one patient each $(1.6 \%)$. Abdulla (2003) reported wound infection in 15 patients (5.5\%), anastomotic leak in 12 patients (4.4\%), hematoma formation in 4 patients $(1.1 \%)$, urinary bladder disturbance in $2.5 \%$, anastomotic stenosis in $1.1 \%$, anastomotic bleeding in $0.7 \%$, abscess formation in $1.1 \%$, seroma in $0.5 \%$, wound dehiscence in one patient $(0.3 \%)^{41}$. Thus, we see that the complications encountered by us are reported in world literature and are not at a variance with the literature.

No operative mortality (defined as death within 30 days) occurred in our series as reported by other authors also ${ }^{11,15,25}$. Simona et al (2003) observed significantly higher mortality rate in emergency treated patients than in elective group. It was $11.9 \%$ in emergency group and $3.4 \%$ in elective group $^{42}$.

Typical adenocarcinoma was present in $80.6 \%$ of our patients. The percentage of patients with typical adenocarcinoma in literature ranges between $65-93 \%$ and correlates well with our series ${ }^{15,20,22,29}$. The degree of differentiation was evaluated. Well differentiated adenocarcinoma was most common (41.9\%) followed by moderately differentiated adenocarcinoma in $21 \%$. Poorly differentiated adenocarcinoma was seen in $17.7 \%$ of patients. Mucinous adenocarcinoma was seen in $12.9 \%$ of our patients and correlates well with reported rate of $13 \%$ by Walton et al (1976) and $11 \%$ by Martin et al (1981) series $^{10,36}$.

None of our patients presented with stage A disease. Stage B was seen in $16.7 \%$, stage $\mathrm{C}$ in $61.7 \%$ and stage $\mathrm{D}$ in $21.7 \%$. The disease stages were almost uniformly distributed between the two sexes. In most studies in literature, majority of young patients present in advanced stage (Stage C or D) as in our study. The patients presenting with advanced stage in our study $(83.4 \%)$ correlates well with the studies in literature as follows:-

$\begin{array}{lc}\text { Authors } & \text { Stage C+D } \\ \text { Howard et al (1975) } & 79 \% \\ \text { Simstein et al (1978) } & 78 \% \\ \text { Safford et al(1981) } & 80 \% \\ \text { Domergue et al(1988) } & 81 \% \\ \text { Present study } & 83.4\end{array}$


Baba PUF; et al; Colorectal Cancer in Young Adult Population in Kashmir

Adjuvant therapy in the form of chemotherapy and/or radiotherapy was given to the patients. $8.3 \%$ of patients were given preoperative chemoradiation with a view to downstage the tumour that was later dealt by surgery. These patients used to receive the chemoradiation post operatively as well. $88.3 \%$ of our patients were subjected to postoperative chemotherapy. All cases of rectal growths received postoperative radiotherapy (20 cycles). Rullier et al (2001) reported that preoperative chemoradiation achieved tumor down staging in $97.7 \%$ of patients. ${ }^{43}$

Patients in our study were on varied follow up, ranging from less than 6 months (for those patients who presented during last few months of study) to 4 years (for retrospective patients). Local recurrence was seen in $13.6 \%$ of our patients and correlates with the reported local recurrence of $14 \%$ by Umpleby et al (1984) $)^{25}$. Metastasis was seen in $25.4 \%$ of patients in our series. Liver was the commonest site $(11.9 \%)$ followed by ovary $(6.8 \%)$. Lung metastasis was seen in $3.4 \%$ of patients, brain metastasis in $1.7 \%$ and metastasis at colostomy site in $1.7 \%$ of patients. Cusack et al (1996) noted liver metastasis in $31 \%$, pelvic in $22 \%$, lung in $14 \%$, bone in $3 \%$.

\section{CONCLUSION}

Colorectal cancer incidence is increasing among young age, in contrast to the decreasing rates observed for adults in the screened population. Bleeding per rectum is the most common presenting symptom followed by altered bowel habits. Endoscopic examination is important prerequisite in any suspected case of colorectal cancer, further colonoscopy having an added advantage of detecting any other synchronous lesion in the colon as well. Outcome of $\mathrm{CRC}$ in young patients is significantly related to the procedure - whether done with curative intention or for palliation. Henceforth, surgical treatment should be radical and optimized with adjuvant therapy where possible to achieve the best prognosis. The diagnosis of colorectal cancer should be done at the early and curable stage for better outcome. Further studies are required to address the early diagnosis and management of colorectal cancer in young adults in our region.

\section{Conflict of Interest- None}

Financial Interest - None

Ethical Issue...None

\section{REFERENCES}

1. Dobre M, Dinu DE, Panaitescu E, Bîrlă RD, Iosif CL, Boeriu $\mathrm{M}$, et al. KRAS gene mutations prognostic factor in colorectal cancer? Rom J MorpholEmbryol 2015; 56:671-8.

2. Calva AM, Acevedo Tirado MT. Revisión y actualización general en cancer colorrectal. Revista de Radiología México. 2009; 1:99-115.

3. Siegel RL, Miller K, Jemal A. Cancer Statistics, 2015. CA Cancer J Clin. 2015; 65:5-29.

4. Smith RET, Renaud RC, Hoffman E. Colorectal cancer market. Nat Rev Drug Discov. 2004;3:471-2.

5. Cancer Facts \& Figures 2016 [Internet]. Cancer.org; 2016 [17 May 2016]. Available from: http://www.cancer.org/acs/groups/content/ @ research/documents/document/acspc-04-7079.pdf.

6. Ferlay J, Soerjomataram I, Ervik M. Globacon 2012 v1.0. Cancer Incidence and Mortality Woridwide: IARC No. 11. Lyon, France: International Agency for Research on Cancer; 2013. Available from: http://www.globacon.iarc.fr. [Last accessed on 2013 Dec 23].

7. BFactSheetsbyPopulation-CRC India ASRs. ^[Online]. Available: http://globocan.iarc.fr/ Pages/fact sheets population.aspx

8. Safford KL, Spebar MJ, Rosenthal D. Review of colorectal cancer in patients under age 40 years. Am J Surg 1981;142:767-769.

9. Kern WH, White WC. Adenocarcinoma of the colon in a 9-month old infant: Report of a case. Cancer 1958;11:855-857.

10. Walton WW, Hagihara PF, Griffen WO.Colorectal adenocarcinoma in patients less than 40 years old. Dis Colon Rectum 1976;19:529-534.

11. Steele GD Jr. The national cancer data base report on colorectal cancer. Cancer 1994; 74:1979-89.

12. Laishram RS, Kaiho N, Shimray R, Devi SB, Punyabati P, Sharma DC. Histopathological evaluation of colorectal carcinomas status in Manipur, India. Int J Pathol 2010;8:5-8.

13. Cohen AM, Minsky BD, Schilsky RL. In: De Vita TV, Hellman S, Rosenberg SA, et al. editors. Cancer: 
Baba PUF; et al; Colorectal Cancer in Young Adult Population in Kashmir

Principles and Practice of Oncology. 4th ed. Philadelphia: J.B. Lippincott Company; 1993.p. 931.

14. Goh KL, Quek KF, Yeo GT, Hilmi IN, Lee CK, Hasnida $\mathrm{N}$, et al. Colorectal cancer in Asians: A demographic and anatomic survey in Malaysian patients undergoing colonoscopy. Aliment PharmacolTher 2005;22:859-64.

15. Singh LJ, Moirangthem GS, Debnath K. Colorectal cancer in younger patients. Trop Gastroentrol 2002; 23:144-145.

16. Soliman AS, Bondy ML, Levin B, Hamza MR Ismail K, Ismail S, Hammam HM, El-Hattab OH, Kamal SM, Soliman AGA, Dorgham LA, McPherson RS, Beasley RP. Colorectal cancer in Egyptian patients under 40 years of age.Int J Cancer 1997;71:26-30.

17. Umpleby HC, Williamson RCN. Carcinoma of the large bowel in the first four decades. Br. J Surg 1984;71:272-277

18. Jarvinen HJ.Time and type of prophylactic surgery for familialadenomatosis coli.Ann Surg 1985; 202:93-97.

19. Adloff M, Arnaud JP, Schloegel M, Thibaud D, Bergamaschi R. Colorectal cancer in patients under 40 years of age. Dis Colon Rectum 1986;29:322-325.

20. Recalde M, Holyoke ED, Elias EG. Carcinoma of the colon, rectum and anal canal in young patients.SurgGynecolObstet 1974;139:909-913.

21. Singh LJ, Moirangthem GS, Debnath K. Colorectal cancer in younger patients. Trop Gastroentrol 2002;23:144-145.

22. Chung YFA, Eu KW, Machin D, Ho JMS, Nyam DCNK, Leong AFPK, Ho YH, Seow-Choen F. Young age is not a poor prognostic marker in colorectal cancer. Br J Surg 1998;85:1255-1259.

23. Bulow S. Colorectal cancer in patients less than 40 years of age in Denmark, 1943-1967. Dis Colon Rectum 1980;23:327-336.

24. Heys SD, O'Hanrahan TJ, Brittenden J, Eremin O. Colorectal cancer in young patients: a review of the literature. Eur J SurgOncol 1994;20:225-231.

25. Umpleby HC, Williamson RCN. Carcinoma of the large bowel in the first four decades. Br. J Surg 1984;71:272-277.
26. Pitluk H, Poticha SM. Carcinoma of the colon and rectum in patients less than 40 years of age. Surg GynecolObstet 1983; 157:335-337.

27. Simstein NL, Kovalcik PJ, Cross GH Colorectal carcinoma in patients less than 40 years of old. Dis Colon Rectum 1978;21:169-171.

28. Hall A, Coffey RJ. Cancer of the large bowel in the young adult. Am J Surg 1961;102:66-72.

29. Cusack JC, Giacco GG, Cleary K, Davidson BC, Izzo F, SkibberJ,Yen J, Curley SA. Survival factors in 186 patients younger than 40 years old with colorectal adenocarcinoma. J Am CollSurg 1996;183:105-112.

30. Iqbal QM, Abdul M. Ganai, Gul M. Bhat, et al. Pattern and magnitude of various cancers registered at regional cancer centre of a tertiary care institute in north India, Int J Community Med Public Health. 2016 Jun;3(6):1672-1680

31. Lee PY, Fletcher WS, Sullivan ES, Vetto JT. Colorectal cancer in young patients: characteristics and outcome. Am Surg 1994;60:607-612.

32. Ezzo JA, Sullivan JF, Mack RE. Carcinoma of the colon under the age of 40. Ann Intern Med 1958;49:321-325.

33. Miller FE, Liechty RD. Adenocarcinoma of the colon and rectum in persons under thirty years of age. Am J Surg 1967;113:507-510.

34. Johnson JW, Judd ES, Dahlin DC.Malignant neoplasms of the colon and rectum in young persons. Arch Surg 1959;79:365-372.

35. Domergue J, Ismail M, Astre C, Saint-Aubert B, Joyeux H, Solassol C, Pujol H. Colorectal carcinoma in patients younger than 40 years of age. Montpellier cancer Institute experience with 78 patients. Cancer 1988;61:835-840.

36. Martin EW, Joyce S, Lucas J, Clausen K, Cooperman M. Colorectal carcinoma in patients less than 40 years of age: pathology and prognosis. Dis Colon Rectum 1981;24:25-28.

37. Alici S, Aykan NF, Sakar B, Bulutlar G, Kaytan E, Topuz E. Colorectal cancer in young patients: characteristics and outcome. Tohoku J Exp Med 2003;199:85-93.

38. Lin JT, Wang WS, Yen EC, Liu JH, Yang MH, Chao 
Baba PUF; et al; Colorectal Cancer in Young Adult Population in Kashmir

TC, Chen PM, Chiou TJ.Outcome of colorectal carcinoma in patients under 40 years of age. J GastroenterolHepatol 2005;20(6):900-905

39. Smith C, Butler JA. Colorectal cancer in patients younger than 40 years of age. Dis Colon Rectum 1989;32:843-846.

40. Ohman U. Colorectal carcinoma in patients less than 40 years of age. Dis Colon Rectum 1982;25:209-214.

41. Abdulla HS. Early postoperative morbidity and mortality of colorectal cancer surgery. JSP International 2003;8(3).

42. Simona A, Giuseppe N, Giulia T, Carlo F, Antonio Z, Enzo P,Paolo C. Early and late outcome after surgery for colorectal cancer: elective versus emergency surgery. Tumori 2003; 89(1):36-41

43. Rullier E, Goffre B, Bonnel C et al. Preoperative radiochemotherapy and sphincter saving resection for T3 carcinomas of the lower third of the rectum. Ann. Surg. 2001 Nov; 234(5): 633-640 